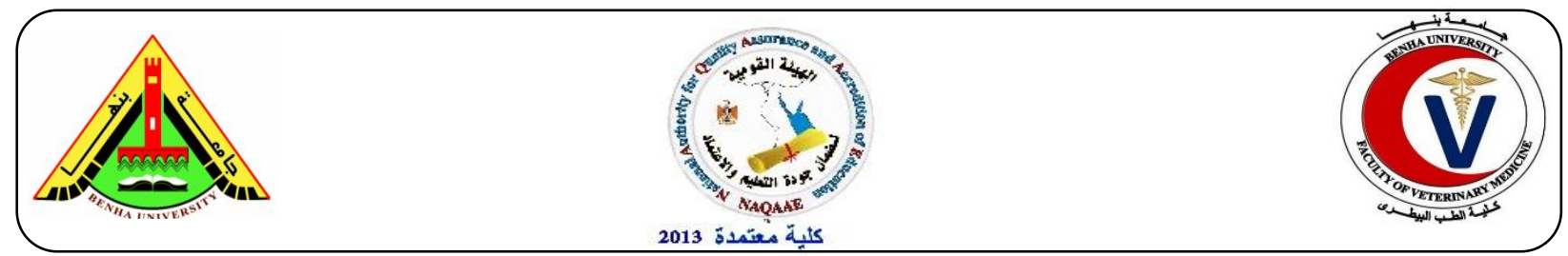

\title{
Trial for Preparation of Combined Equine Influenza virus, Equine Herpesvirus-1 and Tetanus Toxoid Vaccine
}

\author{
Mohamed bayoumi ${ }^{1}$, Abdelmoneim M. Moustafa ${ }^{2}$, Nashwa Madkour ${ }^{1}$, Abdelfattah Selim², \\ Wafaa Abdelazez ${ }^{1}$ \\ ${ }^{1}$ Equine Viral Disease Research Department, Veterinary Serum and Vaccine Research Institute, Abbasia \\ ${ }^{2}$ Animal medicine department, Faculty of Veterinary Medicine, Benha University \\ E-mail: Svri @ idsc.gov.eg
}

\section{A B S T R A C T}

Vaccination remains an important strategy to fight Equine influenza (EI), Equine herpesvirus-1 (EHV1) and tetanus infection, in combination with management measures. A combined inactivated EIV, EHV-1 and Tetanus toxoid (TT) vaccine adjuvanted with saponin and Alhydrogel was prepared and tested in four groups of guinea pigs in comparison with each vaccine separately beside another group as control.

The humoral immune response in vaccinated guinea pigs against EI, EHV-1 and tetanus was evaluated by Haemagglutination Inhibition (HI) antibody titers, Enzyme linked immunosorbent assay (ELISA) titers, and toxin neutralizing (TN) antibody titers respectively. All vaccines proved to be safe and potent in guinea pigs. Also, the obtained antibodies titers with combined vaccine was nearly similar to titer obtained with separated vaccine of each target agent in vaccinated guinea pigs. The evaluation of keeping quality of the prepared combined inactivated vaccine showed that it is was stable at $4^{\circ} \mathrm{C}$ up to 12 months and for 3 months at room temperature.

Key words: Equine influenza, herpesvirus-1, Tetanus toxoid, saponin, Alhydrogel vaccine, Potency (http://www.bvmj.bu.edu.eg) (bvmj, 34(1): 106-116 , MARCH, 2018

\section{INTRODUCTION}

Equine influenza (EI) is highly contagious viral respiratory disease and is characterized by fever, depression, mucoid or mucopurulent discharge, and coughing. Clinical signs develop after a short incubation period. The disease rapidly spread by direct aerosol transmission through a horse population. Indirect transmission can occur as a consequence of inadequate hygienic precautions and co-transport of infected and uninfected horses (Laabassi et al., 2015).
The spread of equine influenza has been associated with the ever-increasing international movement of horses, in particular for breeding and racing purposes (Quinlivan et al., 2004).

The currently available equine influenza vaccines are whole inactivated vaccine, live attenuated vaccine and viral-vector based vaccines (Paillot et al., 2013).

Equine herpesvirus-1 (EHV-1) is one of the major viral pathogens causing respiratory 
disease, abortion, perinatal mortality and neurologic disease among horses resulting in significant economic losses to the equine industry (Pusterla et al., 2016).

The virus can also remain latent for the life time in the horses (Foote et. al., 2006), with subsequent reactivation causing a clinical disease during periods of stress, corticosteroids or drug (Barrandeguy et al., 2008).

Whole inactivated EHV-1 vaccines which provide variable levels of protection against the disease through the induction of antibodies have been the main type of vaccine commercially available (Kapoor et al., 2014).

Tetanus is a fatal bacterial disease caused by an anaerobic spore-forming bacterium Clostridium tetani. This disease is one of the most dramatic and globally prevalent diseases of humans and vertebrate animals. An enormously virulent neurotoxin secreted by the spore which can causes the clinical signs of the disease (Bruggemann et al., 2003).

Horses are the most susceptible of all domestic animals, and the disease is fatal to more than $80 \%$ of affected horses. Infection due to its spore which takes its way to the body via any wounds especially deep lacerated wounds that caused by sharp objects or internal wounds (British Horse Society, 2004).

Vaccination is quick simple and highly effective and only practical mean of long-term protection by using the tetanus toxoid which is the most effective prophylactic immunogens in general use today. Regular vaccination of all horses and ponies against tetanus is absolute essential (Englund et al., 1993).

Vaccination in conjunction with good animal management is the best way to prevent outbreaks of these diseases (Kapoor et al., 2014). An effective vaccine needs not only good antigens but also preferable adjuvant to enhance the immunogenicity of antigen, including humeral and cellular immune responses (Harold and Stills 2005).

Therefore, the present study was planned as a trial for preparation of combined inactivated EIV, EHV-1 and tetanus toxoid vaccine, evaluation of the prepared vaccine in laboratory animals using HI test, ELISA, and TNT and followed by studying the keeping quality of the prepared vaccine in guinea pigs.

\section{Material and Methods}

\subsection{Strains used for vaccine preparations}

The locally identified freeze dried EI virus (A/equi-2/Egypt/6066 NAMRU3-VSVRI/2008) egg passage three and Freeze dried locally isolated EHV-1 at its VERO cell passage two were used for vaccine preparation. The virus was obtained from Equine Viral Disease Research department, Veterinary Serum \& Vaccine Research Institute (VSVRI), Abbasia, Egypt.

Lyophilized C. tetani strain (Harvard strain, 49805) obtained from the Egyptian organization for Biological Products and Vaccines, Tetanus department, Cairo, Egypt.

\subsection{Antigen and antisera used in serological evaluation}

A partially purified antigen of EHV-1 local isolate propagated on VERO cells was prepared as described by Azmi and Field (1993), used in serological tests.

Reference antisera against EI virus- A/equi1/parague/56 (H7N7) and A/equi-2/Miami/63 (H3N8) were obtained from National Veterinary Laboratories, United States Department of Agriculture and Veterinary Services (NVSL, USDA, VS). Freeze dried rabbit anti EHV-1 \& 4 Serum was kindly supplied by Dr. Jennet Wellington, Research follow, Department of 
Trial for Preparation of Combined Equine Influenza virus, Equine Herpesvirus-1 and Tetanus Toxoid Vaccine

biological science, Maquairia University, Australia.

Commercial antitetanic serum was obtained from the Egyptian Organization of Biological Products and Vaccine, Tetanus Department, Egypt. Each ampoule contained $1500 \mathrm{IU} / \mathrm{ml}$. It was used for Lf test, serum neutralization test.

\subsection{Adjuvant}

Aluminum hydroxide with low viscosity (Alhydrogel LV) was made by Superfos Biosector a/s., Denmark. Alhydrogel was used as an adjuvant according to (Eman et al., 2009) and stored at $4-8^{\circ} \mathrm{C}$.

Quillaja extract saponin was obtained from ACROS co. (New Jersey, USA) and used as an adjuvant. It was prepared by dissolving $1 \mathrm{gm}$ per $100 \mathrm{ml}$ MEM and filter-sterilized to yield a 10 $\mathrm{mg} / \mathrm{ml}$ stock (OIE, 2016)

\subsection{Titration of EI and EHV-1 and tetanus toxoid}

Specific pathogen free egg (SPF-ECE) 9-11 days old was inoculated through the allantoic sac route with $0.1 \mathrm{ml}$ of serial tenfold dilution of EI infected egg fluid (4 ECE / dilution) and incubated at $35^{\circ} \mathrm{C}$ for 72 hours, then chilled overnight according to (Tyrrell and Valentine 1957). The infectivity titer expressed in $\log _{10}$ EID $_{50} / 0.1 \mathrm{ml}$ was calculated according to the method described by Reed and Muench (1938).

Serial tenfold dilutions of EHV-1 virus fluid were prepared in sterile PBS, and inoculated into VERO CELLs on tissue culture plate (4 wells/ dilution), and followed by incubation for 5 days at $37^{\circ} \mathrm{C}$. The titer was expressed in $\log _{10} \mathrm{TID} \mathrm{D}_{50} / \mathrm{ml}$ calculated by the method of Reed and Muench (1938).

Tetanus toxoid 80 (limit of flocculation) LF/ml, obtained from serum and antigen department. Veterinary Serum \& Vaccine Research Institute (VSVRI), Abbasia, Egypt.
2.5. Preparation of combined EI, EHV-1 and TT vaccine:

The locally identified freeze dried equine influenza virus (A/equi- 2/Egypt $/ 6066$ NAMRU3-VSVRI/2008) egg passage three (EP3) was propagated for one passage in SPFECE 9-11 days old through the allantoic sac route.

Virus suspension $\left(\mathrm{EP}_{4}\right)$ was harvested after 3 days post inoculation and centrifuged at 1500 rpm for 15 minutes. The supernatant carefully collected and dispensed in convenient vials then stored at $-70^{\circ} \mathrm{C}$ as a Working seed virus. Vaccine virus suspension was prepared from the Working seed virus by one additional passage in SPF- ECE $\left(\mathrm{EP}_{5}\right)$ as described by (OIE, 2016). The virus fluids were harvested, tested for sterility, haemagglutinating activity expressed in $\log _{2}$ (HA unit/0.05 ml) by using HA test and infectivity titer expressed in $\log _{10}$ $\mathrm{EID}_{50} / 0.1 \mathrm{ml}$.

Vaccine virus suspension of EI-Ep5 with HA titer $11 \quad \log _{2}$ and infectivity titer10 $\log _{10}$ $\mathrm{EID}_{50} / 0.1 \mathrm{ml}$ was inactivated with binary ethyleneimine (BEI) at a final concentration $0.003 \mathrm{M}$ with continuous stirring at $37^{\circ} \mathrm{C}$ for 24 hours followed by immediate addition of sterile sodium thiosulphate at a final concentration $2 \%$ to stop the action of BEI on the virus and neutralize the toxic action of residual inactivator on target host.

The locally identified freeze-dried equine EHV-1 seed virus of VEp2 was propagated on VERO cells for two successive passages. Virus fluid (VEP4) was collected after the evidence of $\mathrm{CPE}$, centrifuged at $1500 \mathrm{rpm}$ for 15 minutes. The supernatant fluid carefully collected, tested for sterility and dispensed in convenient vials then stored at $-70^{\circ} \mathrm{C}$ as a Working seed virus. 
Vaccine virus suspension was prepared from the Working seed virus by one additional passages in VERO cells as described by (OIE, 2017).Vaccine virus fluid (VEp5) was centrifuged at $1500 \mathrm{rpm}$ for 15 minutes. The supernatant carefully collected and tested for sterility, titrated and $\mathrm{TCID}_{50} / \mathrm{ml}$ was calculated according to (Reed and Muench, 1938).

The prepared viral fluid with $8 \log _{10}$ TCID $_{50}$ $/ \mathrm{ml}$ was inactivated by $\mathrm{BEI}$ at a final concentration $0.008 \mathrm{M}$ at $37^{\circ} \mathrm{C}$ for 24 hours with continuous stirring as described by Nehal (2006). Sodium thiosulphate at final concentration $2 \%$ was added to stop the action of BEI on the virus and neutralize the toxic action of residual inactivator on target host.

Inactivated fluids of EIV and EHV-1 tested for residual infective virus activity test in ECE and VERO cells respectively to ensure complete inactivation (OIE, 2016 and 2017).

Inactivated virus suspension of EIV and EHV-1and TT were mixed with saponin. 1 $\mathrm{mg} /$ horse dose and 20\% Alhydrogel using magnetic stirrer at $4^{\circ} \mathrm{C}$ for 24 hours, then dispensed in vials, each of them contain $4 \mathrm{ml}$ that representing one horse dose. Each $4 \mathrm{ml}$ of inactivated combined EI, EHV-1\& TT Vaccine should contain not less than $10 \quad \log _{2}$ HA units/0.05ml of EIV (Kucera and Beckenhauer, 1977), $7 \log _{10} \mathrm{TCID}_{50} / \mathrm{ml}$ of EHV-1 (Mayr et al., 1978 ) and $40 \mathrm{LF} / \mathrm{ml}$ ( limit of flocculation) of TT (Heldens et al., 2010; Soliman et al., 2011). All vaccine vials were caped and kept at $4^{\circ} \mathrm{C}$.

Each of inactivated fluids of EIV, EHV-1and TT were mixed separately with saponin 1 $\mathrm{mg} /$ dose and $20 \%$ Alhydrogel using magnetic stirrer at $4^{\circ} \mathrm{C}$ for 24 hours and used for testing the potency of each vaccine separately in comparison with combined vaccine.

\subsection{Sterility test of the prepared vaccine}

Samples were taken from the final product as well as the fluids before and after inactivation process and tested on Nutrient agar medium, Sabauroud dextrose agar medium, Thioglycolate medium (Oxford, England) and PPLO (broth) medium for detection of bacterial fungal and mycoplasma contaminations (OIE, 2016 and 2017)

\subsection{Safety test of the prepared vaccine}

Two pregnant mares at the last third of pregnancy were inoculated I/M with $4 \mathrm{ml}$ of the prepared vaccine each horse received two doses I/M (4ml/dose/horse) with one-month interval. All horses were kept under observation and body temperatures to evaluate the safety of EI vaccine as described by (OIE, 2016)

Group of ten pregnant mice, was inoculated subcutaneously (S/C) with two doses of the prepared vaccine one week apart $(0.2 \mathrm{ml} /$ dose $)$. Mice were kept under observation in a good hygienic condition for two weeks to evaluate safety of EHV-1 vaccine (Slater et al., 1993). In addition, group of five guinea pig were inject by $4 \mathrm{ml}$ of the vaccine subcutaneously as 2 equal divided doses, at separate sites and were kept under observation in a good hygienic condition for 21 days to evaluate tetanus toxoid (European Pharmacopoeia 2008).

2.8. Evaluation the potency of prepared vaccine in guinea pigs

Twenty-five seronegative guinea pigs were divided into 5 groups (5 guinea pigs/group). Group A was inoculated subcutaneously $\mathrm{S} / \mathrm{C}$ with $1.3 \mathrm{ml}$ of inactivated EI vaccine adjuvanted with saponin and Alhydrogel, group B was inoculated S/C with $1.3 \mathrm{ml}$ of inactivated $\mathrm{EHV}-1$ vaccine adjuvanted with saponin and Alhydrogel, group $\mathrm{C}$ was inoculated $\mathrm{S} / \mathrm{C}$ with $1.3 \mathrm{ml}$ of $\mathrm{TT}$ vaccine 
adjuvanted with saponin and Alhydrogel, group $\mathrm{D}$ was inoculated $(\mathrm{S} / \mathrm{C})$ with $4 \mathrm{ml}$ of combined inactivated EI, EHV-land TT vaccine adjuvanted with saponin and Alhydrogel and group E was kept as a control under the same conditions of the experiment.

Twenty-one days post inoculation, serum samples were collected from groups (A, B, D and E). Groups (A, D and E) tested for EI- HI antibody titer using $\mathrm{HI}$ test after being treated with potassium periodate (OIE, 2016). Groups (B, D and E) tested for EHV-1 antibodies using ELISA.

After 21 days post inoculation, groups (B, $\mathrm{C}$ and $\mathrm{D})$ received the second dose of the vaccine then 14 days later, serum samples were collected from group (B, C, D and E), and inactivated at $56^{\circ} \mathrm{C}$ for 30 minutes and examined for EHV-1 antibodies using ELISA (Guo et al.,1989) and tetanus antitoxin titer using TN test (European Pharmacopoeia 2008).

\subsection{Determine the Stability of combined}

inactivated EI, EHV-1 \&TT vaccine:

To study the effect of storage on the prepared vaccine, 160 vials containing combined inactivated EI, EHV-1 \&TT vaccine were divided into two groups; the first group was stored at $4^{\circ} \mathrm{C}$ for 12 months while the second group was stored at room temperature $\left(22-25^{\circ} \mathrm{C}\right)$ for the same period.

Samples from each group of the stored vaccine were taken separately at time intervals $(0,3,6$, 9, 12 months) and examine its potency in guinea pigs (10 guinea pigs for each time). Control group of five guinea pigs was kept without inoculation but under the same conditions of the experiment.

All sera sample tested for EI- HI antibody titer using HI test, EHV-1 antibodies using ELISA and tetanus antitoxin titer using (TN) test.

\section{RESULTS}

\subsection{Safety}

Concerning the vaccine sterility, samples were taken from the final product as well as the fluids before and after inactivation process found to be free from bacterial fungal and mycoplasma contaminations.

In addition, there is no residual virulent virus in the inactivated viral fluids for vaccine safety which was proved by absence of haemagglutinating activity and CPE in both ECE and VERO cells for EIV and EHV-1 respectively.

All inoculated horses showed normal body temperature and no undesirable local or systemic reaction observed following primary and booster injections. There is no abortion in pregnant mares.

Neither abortion nor untoward reaction (roughness, loss of weight, nervous signs, deaths, hypersensitivity) were observed on inoculated mice.

Also, absence of local or systemic reaction or animal death were observed in inoculated guinea pigs except presence of small swelling at the site of inoculation which disappeared within 5 days.

\subsection{Efficacy}

The potency and immunogenicity of the prepared inactivated EI vaccine and combined inactivated EI, EHV-1 and TT vaccine in guinea pig evaluated by $\mathrm{HI}$ test and revealed that the mean EIV antibodies titer at 3 weeks post inoculation (WPI) were (2048) and (2252.8), respectively as shown in table 1 .

Both group of guinea pig (B and D) which vaccinated against EHV-1 revealed that the EHV-1 antibodies were detectable 3 WPI with mean ELISA titer (740) and (775), respectively. A significant increase in the antibody titer (about 2-fold) was observed 2 weeks post the 
second dose with mean ELISA titer (1636) and (1672), respectively as in table 2.

The other groups were vaccinated with tetanus toxoid and the prepared combined vaccine and showed that mean TN antibodies after 2 weeks from boostering dose were (39) and (40) IU/ml respectively, as shown in table 3.

\subsection{Stability}

Regard to the effect of storage at different temperature on the prepared vaccine, Table (4) presents the results of immune responses in guinea pig inoculated with the prepared vaccine kept for different intervals (Zero, 3, 6, 9and 12 months) at $4^{\circ} \mathrm{C}$ and room temperature (25$28^{\circ} \mathrm{C}$ ). The mean $\mathrm{HI}$, tetanus antitoxine and EHV-1 ELISA antibodies titer begin with 2250, $45 \& 775,1672$ respectively at zero time then decreased gradually to $1024,40 \& 550,1200$ after 12 months at $4^{\circ} \mathrm{C}$. While samples of the same vaccine batch kept at room temperature gave negative antibodies titer after three months. From the above mentioned results, the vaccine was stable at $4^{\circ} \mathrm{C}$ up to one year and at room temperature $\left(22-25^{\circ} \mathrm{C}\right)$ for 3 months.

Table 1: EI- HI antibodies titer in sera of guinea pigs inoculated with the prepared vaccine

\begin{tabular}{|c|c|c|c|c|c|c|}
\hline \multirow{3}{*}{$\begin{array}{l}\text { Guinea } \\
\text { pigs No. }\end{array}$} & \multicolumn{6}{|c|}{ EI-HI antibodies titer in guinea pig sera } \\
\hline & \multicolumn{2}{|c|}{ Group (A) } & \multicolumn{2}{|c|}{ Group (D) } & \multicolumn{2}{|c|}{ Group (E) } \\
\hline & $\begin{array}{c}\text { Pre- } \\
\text { inoculation }\end{array}$ & $3 \mathrm{WPI}$ & $\begin{array}{c}\text { Pre- } \\
\text { inoculation }\end{array}$ & 3 WPI & $\begin{array}{c}\text { Pre- } \\
\text { inoculation }\end{array}$ & $3 \mathrm{WPI}$ \\
\hline 1 & - & 2048 & - & 4096 & - & - \\
\hline 2 & - & 4096 & - & 2048 & - & - \\
\hline 3 & - & 2048 & - & 2048 & - & - \\
\hline 4 & - & 1024 & - & 2048 & - & - \\
\hline 5 & - & 1024 & - & 1024 & - & - \\
\hline Mean & - & 2048 & - & 2252.8 & - & - \\
\hline
\end{tabular}

Group E: was kept as a control at the same conditions of the experiments.

WPI: weeks post inoculation. WPB: weeks post boostering.

Table 2: EHV-1 antibodies titer in guinea pig sera inoculated with the prepared vaccines tested by ELISA.

\begin{tabular}{|c|c|c|c|c|c|c|c|c|c|}
\hline \multirow{3}{*}{$\begin{array}{c}\text { Guinea } \\
\text { pigs } \\
\text { No. }\end{array}$} & \multicolumn{9}{|c|}{ EHV-1- antibodies titer in guinea pig sera tested by ELISA } \\
\hline & \multicolumn{3}{|c|}{ Group (B) } & \multicolumn{3}{|c|}{ Group (D) } & \multicolumn{3}{|c|}{ Group (E) } \\
\hline & $\begin{array}{c}\text { Pre- } \\
\text { inoculation }\end{array}$ & 3 WPI & $\begin{array}{c}2 \\
\text { WPB }\end{array}$ & $\begin{array}{c}\text { Pre- } \\
\text { inoculation }\end{array}$ & $3 \mathrm{WPI}$ & $\begin{array}{c}2 \\
\text { WPB }\end{array}$ & $\begin{array}{c}\text { Pre- } \\
\text { inoculation }\end{array}$ & $\begin{array}{c}3 \\
\text { WPI }\end{array}$ & $\begin{array}{c}2 \\
\text { WPB }\end{array}$ \\
\hline 1 & - & 730 & 1650 & - & 790 & 1600 & - & - & - \\
\hline 2 & - & 800 & 1655 & - & 820 & 1700 & - & - & - \\
\hline 3 & - & 770 & 1600 & - & 780 & 1590 & - & - & - \\
\hline 4 & - & 690 & 1575 & - & 700 & 1710 & - & - & - \\
\hline 5 & - & 710 & 1700 & - & 785 & 1760 & - & - & - \\
\hline Mean & - & 740 & 1636 & - & 775 & 1672 & - & - & - \\
\hline
\end{tabular}

Group E: was kept as a control at the same conditions of the experiments.

WPI: weeks post inoculation. WPB: weeks post boostering. 
Table 3: Tetanus antitoxin titer in sera of Guinea pigs inoculated with the prepared vaccines tested by TN test.

\begin{tabular}{ccccccc}
\hline & \multicolumn{5}{c}{ Antitoxin titer (IU/ml) } & \multicolumn{2}{c}{ Group (E) } \\
Guinea pigs No. & \multicolumn{2}{c}{ Group (C) } & \multicolumn{2}{c}{ Group (D) } & \multicolumn{2}{c}{ (E) } \\
& Pre-inoculation & 2 WPB & Pre-inoculation & 2 WPB & Pre-inoculation & 2 WPB \\
\hline 1 & - & 35 & - & 35 & - & - \\
2 & - & 45 & - & 45 & - & - \\
3 & - & 40 & - & 40 & - & - \\
4 & - & 35 & - & 40 & - & - \\
5 & - & 40 & - & 40 & - & - \\
Mean & - & 39 & - & 40 & - & - \\
\hline
\end{tabular}

Table 4: Stability of the prepared combined inactivated EI, EHV-1 \&TT vaccine tested in groups of guinea pigs

\begin{tabular}{|c|c|c|c|c|c|}
\hline \multirow[t]{2}{*}{$\begin{array}{l}\text { Temperature } \\
\text { of storage } \\
\left({ }^{\circ} \mathrm{C}\right)\end{array}$} & \multirow[t]{2}{*}{$\begin{array}{l}\text { Time of } \\
\text { storage }\end{array}$} & \multirow{2}{*}{$\begin{array}{l}\text { The mean HI } \\
\text { antibody titer in } \\
\text { guinea pig sera } \\
\text { *3WPI }\end{array}$} & \multirow{2}{*}{$\begin{array}{c}\text { The mean } \\
\text { Tetanus } \\
\text { antitoxin titer in } \\
\text { guinea pig sera } \\
* * 2 \mathrm{WPB}\end{array}$} & \multicolumn{2}{|c|}{$\begin{array}{l}\text { EHV-1- antibodies } \\
\text { titer in guinea pig sera } \\
\text { tested by ELISA }\end{array}$} \\
\hline & & & & $3 \mathrm{WPI}$ & 2WPB \\
\hline \multirow{5}{*}{$\begin{array}{c}\text { stored at } \\
4^{\circ} \mathrm{C}\end{array}$} & 0 & 2250 & 45 & 775 & 1672 \\
\hline & 3 Months & 2048 & 45 & 727 & 1600 \\
\hline & 6 Months & 2048 & 40 & 690 & 1560 \\
\hline & 9 Months & 1024 & 40 & 610 & 1350 \\
\hline & 12 Months & 1024 & 40 & 550 & 1200 \\
\hline \multirow{5}{*}{$\begin{array}{c}\text { stored at } \\
\text { Room } \\
\text { Temperature } \\
\left(25^{\circ} \mathrm{C}-28^{\circ} \mathrm{C}\right)\end{array}$} & 0 & 2250 & 45 & 775 & 1672 \\
\hline & 3 Months & 512 & 35 & 480 & 820 \\
\hline & 6 Months & 64 & 20 & 110 & 180 \\
\hline & 9 Months & - & - & - & - \\
\hline & 12 Months & - & - & - & - \\
\hline
\end{tabular}




\section{Discussion}

Nowadays vaccination remains an important strategy to fight EI, EHV-1 and tetanus infection in combination with management measures.

In this study, EIV-Ep 5 of HA titer $11 \log _{2} / 0.05$ $\mathrm{ml}$ and infectivity titer $10 \log _{10} \mathrm{TCID}_{50} / 0.1 \mathrm{ml}$ was inactivated with Binary ethylenimine (BEI) at a final concentration $0.003 \mathrm{M}$ at $37^{\circ} \mathrm{C}$ for 24 hours (Eman, 2005), HA titer of the virus after inactivation was not showed any changes. This was in agreement with Kucera and Beckenhaur (1977) who prepared EI (A/equi-2) inactivated vaccine from the field strain with $9 \log _{2}$ to 10 $\log _{2}$ hemagglutinating units.

EHV-1 VEp5 with infectivity titer $8 \log _{10}$ $\mathrm{TCID}_{50} / \mathrm{ml}$ was inactivated with (BEI) at a final concentration $0.008 \mathrm{M}$ at $37^{\circ} \mathrm{C}$ for 24 hours (Nehal, 2006). This titer recommended for preparation of inactivated vaccine (Mumford and Bates, 1984).

Tetanus toxoid with 80 LF (limit of flocculation)/ml was used in preparation of vaccine. This was in agreement with Heldens et al., (2010) who recorded that tetanus Toxoid with $40 \mathrm{LF} /$ horse dose in commercially available vaccine protect from infection.

Concerning the vaccine safety and sterility, samples were taken from the final product as well as the fluids before and after inactivation process, proved to be sterile, free from all contaminant and safe in vivo (VERO cells) and in vetro (ECE, laboratory animals and horses).

The potency and immunogenicity of the prepared vaccines in guinea pig which inoculated with inactivated EI vaccine and combined vaccine, showed that the mean EIV antibodies titer tested by HI test exceeded the protective level against EIV at 3 WPI as previously reported by (OIE, 2016). These obtained results come in accordance with (Eman et al., 2009; Soliman et al., 2011; Nashwa et al., 2012), they tested the potency of EI vaccine in guinea pigs as preliminary study to complete the study in natural host (horses).

Guinea pig were inoculated with inactivated EHV-1 vaccine and combined vaccine, showed that a significant increase in the ELISA antibody titer (about 2-fold) at 2 weeks post second dose. This result in agree with Ackermann et al., (1987) who vaccinated guinea pig with various dilutions of commercial as well as experimental EHV-1 vaccines and found that the induced antibody response correlated well with the amount of antigen used for vaccination. Also, Guo et al., (1989) previously found 2-fold increase in ELISA antibody titer of inoculated guinea pig with EHV vaccine.

Moreover, the mean Tetanus antitoxin titers in guinea pig serum samples which inoculated with tetanus toxoid vaccine and 2 weeks from boostering dose were above the protective level as recorded by (European Pharmacopoeia, 2008), they reported that toxin neutralizing antibody titer should not less than 30 IU for evaluating the potency of tetanus vaccine for equines.

The results of current study revealed that the antibodies titer obtained in guinea pig inoculated with combined vaccine is nearly the same as that obtained from guinea pig inoculated with each vaccine separately which in concordance with (Soliman et al., 2011: Nashwa et al., 2016).

The prepared vaccine was stable at $4^{\circ} \mathrm{C}$ up to 12 months and for 3 months at room temperature as previously mentioned by OIE, (2017), inactivated vaccine products generally 
maintain their original antigenic potency for at least 1 year when stored at $4^{\circ} \mathrm{C}$.

In conclusion, the prepared combined EI, EHV1 and TT vaccine was safe potent and stable at $4^{\circ} \mathrm{C}$ for 12 months and further work is needed by tracing the immunoefficiency of the prepared vaccine in horses (target animal).

\section{REFERENCES}

ACKERMANN, $\quad$ M., GRÜNINGER, S., BRUCKNER, L., . MÜLLER, H.K. AND KIHM, U. 1987: A simple ELISA for the estimation of antibodies to equine herpes virus (EHV-1) and its application to the quality control of vaccines Modern Approaches to Animal Cell Technology, Pages 613627.

AZMI, M. AND FIELD, H. J. 1993. Interactions between equine herpesvirus type 1 and equine herpesvirus type 4: $\mathrm{T}$ cell responses in a murine infection model. Journal of generalvirology, 74,2339-2345.

BARRANDEGUY, M., VISSANI, A., OLGUIN, C., BECERRA, L., MIÑO, S., PEREDA. A., ORIOL, J. AND THIRY, E. 2008. Experimental reactivation of equine herpesvirus-3 following corticosteroid treatment. Equine Veterinary Journal, 40(6): $593-595$.

BRITISH HORSE SOCIETY. 2004. Advise on tetanus \& Influenza vaccination for horses and ponies

BRÜGGEMA, N.N., H., BÄUMER, S., FRICKE, W. F., WIEZER, A., LIESEGANG, H., DECKER, I., HERZBERG, C., MARTINEZARIAS, R., MERKL, R. AND
HENNE, A. 2003. The genome sequence of Clostridium tetani, the causative agent of tetanus disease. Proceedings of the National Academy of Sciences, 100, 13161321.

EMAN, M. 2005. Trials for preparation of killed adjuvated vaccine for equine influenza. Ph.D.

Thesis, Faculty of Veterinary Medicine, Cairo University.

EMAN, M. EBIED, NEHAL S. SALEH, NASHWA K. MADKOUR, EL-

KABBANY, M.M.A. AND

SOLIMAN, I.M.A. 2009. Trial for preparation of monovalent inactivated equine influenza vaccine.

ENGLUND, J.A., MBAWUIKE, I.N., HAMMILL, H., HOLLEMAN, M.C., BAXTER, B.D. AND GLEZEN, W.P. 1993. Maternal immunization with influenza or tetanus toxoid vaccine for passive antibody protection in young infants. Journal of Infectious Diseases, 168, 647-656.

EUROPEAN PHARMACOPOEIA 2008, Vaccines. Tetanus vaccine for veterinary use 957:959.

FOOTE, C.E., LOVE. D.N., GILKERSON. J.R., WELLINGTON, J.E. AND WHALLEY, J.M. 2006. EHV-1 and EHV-4 infection in vaccinated mares and their foals.Veterinary Immunology and Immunopathology, 111, pp.41-46.

GUO, P., GOEBEL, S., DAVIS, S., PERKUS, M.E., LANGUET, B., DESMET'RAE, P., ALLEN, G.P. 
and PAOLETrt, E. 1989. Expression in recombinant vaccinia virus of the equine herpesvirus 1 gene encoding glycoprotein gpl3 and protection of immunized animals. Journal of Virology, 63, 4189-4198

HAROLD, F. AND STILLS, J. 2005. Adjuvants and Antibody Production: Dispelling the Myths Associated with Freund's Complete and Other Adjuvants. ILAR Journal. 46:28

HELDENS, J.G.M., POUWELS, H.G.W., DERKS, C.G.G., VAN DE ZANDE, S.M.A. AND HOEIJMAKERS, M.J.H. 2010. Duration of immunity induced by an equine influenza and tetanus combinationvaccine formulation adjuvanted with ISCOMMatrix. Vaccine, 28, 6989-6996 22.

KAPOOR, S., SHARMA, H., SINGH, M., KUMAR, P., RANJAN, K., KUMARI, A. AND KHIRBAT, R. 2014. Equine herpesviruses: a brief review. Advanced Animal Veterinary Science, 2 (2S): 46 - 54. WHO 2007= EXPERT COMMITTEE ON BIOLOGICAL

STANDERDIZATION Geneva- 8 to 12 October 2007.

KUCERA, C. AND BECKENHAUER, W. 1977. Studies on the antigenicity of an inactivated, aluminum hydroxide adjuvant equine influenza vaccine. Canadian Journal of Comparative Medicine, 41, 326

LAABASSI, F., LECOUTURIER 'F., AMELOT, G., GAUDAIRE, D., MAMACHE, B., LAUGIER, C., LEGRAND, L., ZIENTARA, S. \& HANS, A. 2015. Epidemiology and genetic characterization of $\mathrm{H} 3 \mathrm{~N} 8$ equine influenza virus responsible for clinical disease in Algeria in 2011. Transboundary and emerging diseases, 62, 623-631. OIE 2016. Equine Influenza. Chapter 2.5.7, 115.

MAYR, A., THEIN, P. \& SCHEID N. 1978. Immunization experiments with inactivated EHV-1 in proceeding 4th Int. Conf. Equine Infect. Dis. Lyon edited by Bryans J.T. and Gerber Vet Pub Inc princtone, New Jersey, P.P. 57-67.

MUMFORD, J.A. AND BATES, J. 1984. Trials of an inactivated equine herpesvirus- 1 vaccine; challenge with a subtype 2 virus. Veterinary Record, 114: 375-381.

Nashwa, K., Madkour, Eman, M., Ebeid, Nehal, S., Saleh, Fatma, F., Yosef, El-Kabbany M.M.A. and Soliman I.M.A. 2016. Duration of immunity induced by combined vaccine against Equine influenza and Equine herpesvirus-1, Veterinary Medical Journal - Giza VMJG Vol.62 Conference Issue Jan. (2016 ) ISSN1110-1423

NEHAL SALEH. 2006. preliminary trials for production of equine viral abortion inactivated vaccine, Ph.D.theisis, virology, Benha University.

OIE TERRESTRIAL MANUAL 2016.. Equine Influenza. Chapter 2.5.7, 1-16

OIE TERRESTRIAL MANUAL 2017. Equine rhinopneumonitis Chapter 2.5.9, 113. 
PAILLOT, R., PROWSE, L., MONTESSO, F., HUANG, C., BARNES, H. \& ESCALA, J. 2013. Whole inactivated equine influenza vaccine: Efficacy against a representative clade 2 equine influenza virus, IFNgamma synthesis and duration of humoral immunity. Veterinary microbiology, $162,396-407$.

PUSTERLA, N., MAPES, S., AKANA, N., BARNETT, C., MACKENZIE, C., GAUGHAN, E., CRAIG, B., CHAPPELL, D. \& VAALA, W. 2016. Prevalence factors associated with equine herpesvirus type 1 infection in equids with upper respiratory tract infection and/or acute onset of neurological signs from 2008 to 2014. Veterinary Record, 178, 70-70.

QUINLIVAN, M., CULLINANE, A., NELLY, M., VAN MAANEN, K., HELDENS, J., ARKINS, S., 2004. Comparison of sensitivities of virus isolation, antigen detection, and nucleic acid amplification for detection of equine influenza virus. Journal of Clinical Microbiology, 42, 759-763.

REED, L. J. AND MUENCH, H. 1938. A SIMPLE METHOD OF ESTIMATING FIFTY PER CENT ENDPOINTS 12 . American journal of epidemiology, 27, 493-497.

SLATER, I.D., GIBSON, J.S. AND FIELD, H.J. 1993. Pathogenicity of thymidine kinase-deficient mutant of EHV-I in mice and specific pathogen free foals. Journal of General Virology, 74 (5): 819-828.
SOLIMAN, I. M.A., EL-MENEISY, A.A., NASHWA K. MADKOUR, EL HELW,H .A.EMAN M. EBIED, NEHAL S. SALEH AND MAGDA

A. KALAD 2011. Preparation of Combined Equine Influenza and Tetanus Toxoid vaccine. Veterinary Medical Journal Giza, 59, 353-363.

TYRRELL, D. AND VALENTINE, R. 1957. The assay of influenza virus particles by haemagglutination and electron microscopy. Microbiology, 16, 668675. 